\title{
IDENTIFICATION OF MULTIPLE LEAF RUST RESISTANCE GENES IN SELECTED GERMPLASM OF PAKISTANI BREAD WHEAT USING MOLECULAR MARKERS
}

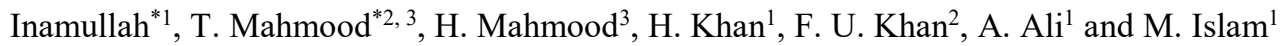 \\ ${ }^{1}$ Department of Genetics, ${ }^{2}$ Department of Agriculture, ${ }^{3}$ Department of Bioinformatics, Hazara University Mansehra, \\ Pakistan \\ *Corresponding author(s): drinamullah34@gmail.com; tmahmood74@hu.edu.pk
}

\begin{abstract}
Leaf rust, caused by Puccinia triticina f. sp. tritici, is the most prevalent disease of wheat in Pakistan. Host resistance is the most effective and economical method of controlling the disease. In the present study, 254 Pakistani wheat germplasm were screened for the presence or absence of 17 leaf rust resistance $(L r)$ genes. $L r 09,10,20,24,25,27,28$, $29,35,37,39,46,47,50,51,58$ and $\operatorname{Lr} 61$ were detected either as pyramided triplet and doublet genes, or as a single gene harbored varieties/germplasm. Triple and double gene pyramids were detected in 9 and 50 varieties/germplasm, respectively, while single $\mathrm{Lr}$ genes were detected in 29 varieties/germplasm. Genotype 10731, having the $\operatorname{Lr} 28 / \operatorname{Lr} 35$ combination, was the leading one with highest grain yield of $20.62 \mathrm{~g} /$ plant. Other leading germplasm were 10754, 10767 and 10758, having combinations of $\operatorname{Lr} 28 / \operatorname{Lr} 35, \operatorname{Lr} 28 / \operatorname{Lr} 29$ and $\operatorname{Lr} 25 / \operatorname{Lr} 27$, and grain yield of 18.84, 16.63 and 15.65, respectively. Ata Habib, with triplet pyramid of $L r 27 / L r 50 / L r 51$, was the leading cultivar with $12 \mathrm{~g} / \mathrm{plant}$ grain yield. Identification of $L r$ genes in Pakistani wheat germplasm will help accelerate the current programs of breeding for resistance to leaf rust in the varieties/germplasm of interest.
\end{abstract}

Key words: Leaf rust, Puccinia triticina, germplasm, $L r$ genes, PCR, Wheat, MAS. https://doi.org/10.36899/JAPS.2021.2.0235

Published online October 03,2020

\section{INTRODUCTION}

Wheat is among the highest cultivated cereals due to its broad-spectrum adaptation, uses and production, and is grown by nearly half of the world population as a principal food (Inamullah et al. 2006; Paux et al. 2008). Because of its huge impact on human life, the crop has also been termed as miracle crop. Wheat has a huge impact on global civilization and provides $20 \%$ of food calories and proteins, and is cultivated over 220 million hectares of land worldwide, producing 670 million tons of grains annually (Shiferaw et al. 2013). Furthermore, the global demand for wheat is increasing with rising human population. As to any other crop, wheat also faces the problems of both abiotic and biotic stresses. Biotic stresses include threats from different rust pathogens, which severely affect wheat productivity. For example, the stem rust alone was estimated to cause a loss of US\$ 1-2 billion in Asia (Jin and Singh, 2006). The epidemic caused by stripe rust was severe in late sowing varieties in the Khyber Pakhtunkhwa province of Pakistan. Even the early sowing varieties which escaped the epidemics inflicted a loss of approximately US\$ 100 million in the province. One of the economically important rust diseases is the leaf rust of wheat, caused by fungal pathogen Puccinia triticina. The disease greatly affects the wheat production, to the extent, that the loss goes upto $50 \%$ and beyond in case of severe incidences (Singh and Hughes, 2006). In addition to cultural practices like cropping intensity and monocropping, the nature of the disease resistance genes distributed in the population of a crop variety also affects the intensity of rust occurrence. Uniformity of disease resistant genes in a cultivar, for example, increases the occurrence of rust. The scenario provides an apt environment for the pathogen to rapidly evolve, arising into a new rust pathotype, and turning a previously resistance host gene into susceptible one (Marasas et al. 2004).

Developing host resistance is effective, economically feasible, and environment friendly approach to contain wheat rust (Vanzetti et al. 2011). Utilization of new sources of resistance from collected germplasm and transfer of resistance gene(s) in the adapted wheat cultivars is an effective strategy toward this end (Singh et al. 2011). Resistance is, essentially, achieved by the products of $R$ genes in the plant and an associated avirulent (avr) gene of the pathogen. The Avr$\mathrm{R}$ interaction elicits a cascade of pathogen race-specific responses in the host, resulting into the establishment of dominant resistance (Dangl and Jones, 2001). Identification of leaf rust $(L r)$ candidate $R$ genes in wheat cultivars and germplasm as source of resistance and their introgression into a cultivar is the best approach and a stepping stone for a successful breeding program. The strategy helps avoid the prevalence of cultivars which are genetically uniform and homozygous for susceptibility genes (Messmer et al. 2000 and Mebrate et al. 2008). 
DNA markers are effective tools to detect genes of interest in the host germplasm and are widely being used in the breeding for resistance against wheat rust, an alternative to the traditional approach of gene postulation, including gene interactions and expression at different growth stages of the plant. Advancements in the $L r$ genes mapping and development of markers for many $L r$ genes have paved the way for markers assisted selection (MAS) to characterize individual genotypes in the advanced breeding programs (Helguera et al. 2000, 2003, 2005; Gupta et al. 2006; Lagudah et al. 2006). Recently, a QTL genetic marker was co-localized for yellow rust on chromosome 6BL in wheat (Zeng et al. 2019). Similarly, the leaf and yellow rust genes have been fine mapped to 5D chromosome of Aegilops peregrine, a wild relative of common wheat (Narang et al. 2019). MAS is therefore, a helpful tool to identify cultivars harboring alleles for the traits of interest at specific loci, and develop varieties of improved yield and high rust resistance in wheat. Furthermore, MAS not only corroborates the authenticity of conventional breeding and its associated QTL analysis but also shortens the time required for a variety development. Detection of $L r$ gene(s) present in selected Pakistani germplasm of bread wheat using molecular DNA markers is reported in the present study. It is an effort to categorize the selected germplasm into different batches based on the presence/absence of the corresponding $\operatorname{Lr}$ gene(s).

\section{MATERIALS AND METHODS}

Plant material: Common wheat varieties and germplasm consisting of 254 genotypes, and acquired from Plant Genetic Resources Institute (PGRI) Islamabad and Cereal
Crop Research Institute (CCRI) Nowshera, were grown in the field at Hazara University Mansehra. The selected genotypes were characterized for various yield contributing traits and leaf rust resistance genes $\operatorname{Lr} 09$, $10,20,24,25,27,28,29,35,37,39,46,47,50,51,58$ and $\operatorname{Lr} 61$ by employing molecular markers viz: STS, SSR, CAPS and SCAR etc.

DNA extraction: Genomic DNA was isolated from young leaves using the protocol of Brunel (1992).

Molecular markers-based identification of leaf rust genes: The basic information regarding all the 17-leaf rust resistant genes using different molecular markers, primers sequences, annealing temperature and expected product size along with the original references is given in Table 1 .

Polymerase chain reaction for 37 cycles was carried out in a total volume of $25 \mu \mathrm{l}$ having $50 \mathrm{ng}$ of template DNA using Applied Biosystems 2720 Thermal Cycler. Other ingredients of PCR included 10xTaq buffer (Fermantos), $5 \mathrm{U}$ Taq DNA polymerase enzyme (Fermantos), 10mM of each deoxynucleotides (AGTC), $10 \mu \mathrm{M}$ of each primer and $2.5 \mathrm{mM}$ of $\mathrm{MgCl}_{2}$. The PCR program consisted of $94{ }^{\circ} \mathrm{C}$ for $1 \mathrm{~min}$ as denaturation temperature followed by $50-64 \circ \mathrm{C}$ for $1 \mathrm{~min}$ as annealing temperature and $72{ }^{\circ} \mathrm{C}$ for $1 \mathrm{~min}$ as extension temperature and a final extension round of $72{ }^{\circ} \mathrm{C}$ for $10 \mathrm{~min}$. Amplification products were visualized under UV light using gel doc system.

Data analysis: Statistical analysis was performed through R-packages for the presence of different $\mathrm{Lr}$ genes as triplet, doublet or singlet, in the varieties/germlasm in the present study.

Table 1. Primers associated with 17 molecular marker $\mathrm{Lr}$ genes and the relevant parameters.

\begin{tabular}{|c|c|c|c|c|c|c|}
\hline $\begin{array}{l}\text { S. } \\
\text { No }\end{array}$ & $\begin{array}{l}\text { Leaf } \\
\text { rust } \\
\text { gene }\end{array}$ & $\begin{array}{l}\text { Marker } \\
\text { used }\end{array}$ & Olegonucleotide sequences & $\begin{array}{l}\text { Annealing } \\
\text { temp }\left({ }^{\circ} \mathrm{C}\right)\end{array}$ & $\begin{array}{l}\text { Required } \\
\text { band size }\end{array}$ & Reference \\
\hline 1 & Lr 09 & STS & $\begin{array}{l}\text { TCCTTTTATTCCGCACGCCGG } \\
\text { CCACACTACCCCAAAGAGACG }\end{array}$ & 58 & $1100 \mathrm{bp}$ & $\begin{array}{l}\text { Schachermayr et } \\
\text { al. } 1994\end{array}$ \\
\hline 2 & Lr 10 & STS & $\begin{array}{l}\text { GTGTAATGCATGCAGGTTCC } \\
\text { AGGTGTGAGTGAGTTATGTT }\end{array}$ & 55 & $310 \mathrm{bp}$ & $\begin{array}{l}\text { Schachermayr et } \\
\text { al. } 1997\end{array}$ \\
\hline 3 & $\operatorname{Lr} 20$ & STS & $\begin{array}{l}\text { GCGGTGACTACACAGCGATGAAGCAATGAAA } \\
\text { GCGGTGACTAGTCCAGTTGGTTGATGGAAT }\end{array}$ & 52 & $542 \mathrm{bp}$ & $\begin{array}{l}\text { Neu and Keller, } \\
2002\end{array}$ \\
\hline 4 & $\operatorname{Lr} 24$ & STS & $\begin{array}{l}\text { TCTAGTCTGTACATGGGGGC } \\
\text { TGGCACATGAACTCCATACG }\end{array}$ & 60 & $310 \mathrm{bp}$ & $\begin{array}{l}\text { Schachermayr et } \\
\text { al. } 1995\end{array}$ \\
\hline 5 & $\operatorname{Lr} 25$ & SCAR & $\begin{array}{l}\text { CCACCCAGAGTATACCAGAG } \\
\text { CCACCCAGAGCTCATAGAA }\end{array}$ & 58 & $1800 \mathrm{bp}$ & $\begin{array}{l}\text { Procunier et al. } \\
1995\end{array}$ \\
\hline 6 & Lr 27 & EST & $\begin{array}{l}\text { GGGTGCACATCCATTGACTTT } \\
\text { TTCTCTCAAGAGCGGGTGCT }\end{array}$ & 60 & $393 \mathrm{~kb}$ & Mago et al. 2011 \\
\hline 7 & $\operatorname{Lr} 28$ & STS & $\begin{array}{l}\text { CCCGGCATAAGTCTATGGTT } \\
\text { CAATGAATGAGATACGTGAA }\end{array}$ & 50 & 378 bp & Naik et al. 1998 \\
\hline 8 & Lr 29 & SCAR & $\begin{array}{l}\text { GTGACCTCAGGCAATGCACAGT } \\
\text { GTGACCTCAGAACCGATGTCCATC }\end{array}$ & 64 & 900 bp & $\begin{array}{l}\text { Procunier et al. } \\
1995\end{array}$ \\
\hline 9 & Lr 35 & STS & AGAGAGAGTAGAAGAGCTGC & 51 & $900 \mathrm{bp}$ & Gold et al. 1999 \\
\hline
\end{tabular}




\begin{tabular}{|c|c|c|c|c|c|c|}
\hline 10 & Lr37 & CAPS & $\begin{array}{l}\text { AGAGAGAGAGCATCCACC } \\
\text { GGTCGCCCGGGCTTGCACCT } \\
\text { TGCAGCTACAGCAGTATGTACACAAAA }\end{array}$ & 64 & $285 \mathrm{bp}$ & $\begin{array}{l}\text { Helguera et al. } \\
2003\end{array}$ \\
\hline 11 & $\operatorname{Lr} 39$ & SSR & $\begin{array}{l}\text { CCTGCTCTGCCCTAGATACG } \\
\text { ATGTGAATGTGATGCATGGCA }\end{array}$ & 56 & $160 \mathrm{bp}$ & Raupp et al. 2001 \\
\hline 12 & Lr46 & SSR & $\begin{array}{l}\text { AGGGAAAAGACATCTTTTTTTTC } \\
\text { CGACCGACTTCGGGTTC }\end{array}$ & 50 & 110 bp & $\begin{array}{l}\text { Rosewarne et al. } \\
2006\end{array}$ \\
\hline 13 & Lr47 & CAPS & $\begin{array}{l}\text { GCTGATGACCCTGACCGGT } \\
\text { TCTTCATGCCCGGTCGGGT }\end{array}$ & 55 & 487 bp & $\begin{array}{l}\text { Helguera et al. } \\
2000\end{array}$ \\
\hline 14 & $\operatorname{Lr} 50$ & SSR & $\begin{array}{l}\text { gtcagataacgccgtccaat } \\
\text { ctacgtgcaccaccattttg }\end{array}$ & 56 & 139 bp & $\begin{array}{l}\text { Brown-Guedira } \\
\text { et al. } 2003\end{array}$ \\
\hline 15 & $\operatorname{Lr} 51$ & CAPS & $\begin{array}{l}\text { gcatcaacaagatattcgttatgacc } \\
\text { tggeggetcagaaaactggacc }\end{array}$ & 60 & $783 \mathrm{bp}$ & $\begin{array}{l}\text { Helguera et al. } \\
2005\end{array}$ \\
\hline 16 & $\operatorname{Lr} 58$ & SSR & $\begin{array}{l}\text { TTCTGCAACATTTTGTCCCA } \\
\text { CGTATGATCCTAACGAGGGC }\end{array}$ & 60 & $261 b p$ & $\begin{array}{l}\text { Kuraparthy et al. } \\
2007\end{array}$ \\
\hline 17 & $\operatorname{Lr} 61$ & SSR & $\begin{array}{l}\text { cAAATTTggecAccATTTTAcA } \\
\text { cggTTcAATccTTggATTTAcA }\end{array}$ & 55 & $160 \mathrm{bp}$ & $\begin{array}{l}\text { Herrera-Foessel } \\
\text { et al. } 2005\end{array}$ \\
\hline
\end{tabular}

Table 2. Germplasm studied in the present study.

\begin{tabular}{|c|c|c|c|c|}
\hline S. No & Group & $\begin{array}{l}\text { Number of } \\
\text { genes studied }\end{array}$ & $\begin{array}{l}\text { Number of } \\
\text { germplasm }\end{array}$ & Germplasm \\
\hline 1 & Group I & 5 & 52 & $\begin{array}{l}11882,10818,10821,10819,10879,10878,10814,10875,10730,10815, \\
10816,10813,10877,10738,10817,10771,10803,10726,10772,10727, \\
10718,10732,10801,11876,10808,10809,11863,10717,10735,10810, \\
10759,10725,10755,10733,10719,10780,10740,10743 \text {, Lasani08, } \\
\text { Faisalabad08, Uqab2000, gomal, suleman, NARC 2009, Sahar 2006, Dera 98, } \\
\text { Atta-Habib, KT 2000, Kaghan-93, Pak- 81, PS 85, Tatara. }\end{array}$ \\
\hline 2 & $\begin{array}{l}\text { Group } \\
\text { II }\end{array}$ & 4 & 52 & $\begin{array}{l}10805,10799,10798,10758,10802,10748,10804,10786,10742,10797, \\
10807,10751,10800,10787,10789,10792,10760,10794,10791,10724, \\
10793,10776,10761,10715,10795,10784,10769,10782,10766,10765, \\
10778,10796,10768,10746,10783,10790,10762,10785 \text {, Lasani-2008, FSD } \\
\text { 2008, Auqab-2000, Gomal, Suleman-96, NARC- 2009, Sahar-2006, Dera 98, } \\
\text { Atta - habib, KT 2000, Kaghan-93, Pak 81, PS-85, Tatara. }\end{array}$ \\
\hline 3 & $\begin{array}{l}\text { Group } \\
\text { III }\end{array}$ & 2 & 48 & $\begin{array}{l}\text { Punjab96, Mumal2002, Zamindar80, Iqbal2000, SH2003, Anmo191, LU26, } \\
\text { Chenab96, Faisalabad83, Zarghoon79, C228, Shahkar95, Punjab88, Nuri70, } \\
\text { Punjab81, C591, Sutlag86, C250, Blue silver, RWP94, Sariab92, Wafaq2008, } \\
\text { Anza+2NS, Lr51YR, AUP5000, WL711, SA75, SA42, Marwat01, Barani83, } \\
\text { Potohar93, Kohinoor83, Potohar70, Pak81, Pirsabak85, C273, Tandojam83, } \\
\text { Dirk, Bahalwapur79, Lasani08, Sussi, Khyber79, FPD08, Sandal, Kiran, } \\
\text { Wardak85, Meraj08, C518 }\end{array}$ \\
\hline 4 & $\begin{array}{l}\text { Group } \\
\text { IV }\end{array}$ & 3 & 51 & $\begin{array}{l}11868,10854,10853,10850,10849,10825,10845,10847,10862,10860, \\
10861,10866,10809,10873,10842,10841,10833,10843,10848,10832, \\
10829,10852,10834,11831,10835,10830,11865,10826,10822,10881, \\
10828,10824,10874,10827,10864,10820,10867, S h a f a q 2006, \text { PS2004, } \\
\text { Siran2010, Noshera96, Khyber87, Wafaq, Hashim, PS08, Zam, Saleem2000, } \\
\text { PS05, Janbaz, Haider2000, ARE10 }\end{array}$ \\
\hline 5 & $\begin{array}{l}\text { Group } \\
\text { V }\end{array}$ & 3 & 51 & $\begin{array}{l}\text { 11880, 10750, 10777, 10781, 10752, 10775, 10774, 10744, 11872, 10753, } \\
10770,10736,10812,10779,10741,11870,10763,10757,10739,11871, \\
10731,10773,10764,10745,10806,10716,10767,10749,11869,10754, \\
10722,10728,10720,10721,10756,10787,10788, \text { Shafaq2006, PS2004, } \\
\text { Siran2010, Noshera96, Khyber87, Wafaq, Hashim, PS08, Zam, Saleem2000, } \\
\text { PS05, Janbaz, Haider2000, ARE10 }\end{array}$ \\
\hline & Total & 17 & 254 & \\
\hline
\end{tabular}

\section{RESULTS}

Uncovering the genetic background of commercially important wheat cultivars is important for deployment of the disease resistance genes and development of molecular markers. In the present study, 254 genotypes and varieties of Pakistani wheat germplasm were screened for the presence of $17 \mathrm{Lr}$ genes via PCR using the primers specific to the respective $L r$ genes (Tables 1,2). 
The germplasm/varieties in the current study were grouped into three categories relative to the number of $L r$ genes present in them. The germplasm/varieties either harbored triple or double $L r$ genes pyramided or single $\mathrm{Lr}$ gene present in the corresponding category. Based on literature, a wheat plant produces approximately 250 grains on average, while 1000 wheat grains weigh approximately 40 grams (Afzal and Iqbal, 2015). By this account, $10 \mathrm{~g} /$ plant grain weight, as an arbitrary cut off value, was set for selection of a cultivar/germplasm with $L r$ gene marker (Afzal and Iqbal, 2015).

A total of 9 varieties/germplasm contained a set of triple genes pyramided in them. Ata Habib, with triplet combination of $L r 27 / L r 50 / L r 51$ was the leading cultivar with $12 \mathrm{~g} /$ plant grain yield. Other cultivars with triplet $L r$ genes were Kaghan 93 and Faisalabad 08, having the $L r$ combinations of $\mathrm{Lr} 27 / \mathrm{Lr} 37 / \mathrm{Lr} 47$ and $\mathrm{Lr} 47 / \mathrm{Lr} 50 / \mathrm{Lr} 51$, and grain yield of $11.53 \mathrm{~g} / \mathrm{plant}$ and $10 \mathrm{~g} / \mathrm{plant}$, respectively. The germplasm 10879 had the combination of Lr37/Lr47/Lr50 and grain yield of $11.25 \mathrm{~g} / \mathrm{plant}$ (Table $3)$.

Fifty varieties/ germplasm were naturally pyramided with double $L r$ genes. Germplasm 10731, having the Lr28/Lr35 combination, was the leading germplasm with highest grain yield of $20.62 \mathrm{~g} / \mathrm{plant}$. Other leading germplasm included 10754, 10767 and 10758, having combinations of $\operatorname{Lr} 28 / \mathrm{Lr} 35, \operatorname{Lr} 28 / \mathrm{Lr} 29$ and $L r 25 / L r 27$, and grain yield of $18.84,16.63$ and 15.65 , respectively (Table 3 ).

There were eleven $\mathrm{Lr}$ genes present as a singlet in 29 varieties/germplasm, out of which 12 varieties/germplasm harbored Lr61. Further, 10822 and 11881 were among the highest yielding varieties/germplasm which harbored Lr61 with 19.53 $\mathrm{g} /$ plant and $16.14 \mathrm{~g} /$ plant grain yield, respectively (Table $3)$.

Table 3. PCR-based detection of $\mathrm{Lr}$ gene markers as triplet, doublet and singlet, and grain yield/plant in the selected bread wheat varieties/germplasm.

\begin{tabular}{|c|c|c|}
\hline Lr Genes & Germplasam & Grain yield/plant (grams) \\
\hline Lr20, Lr25, Lr27 & 10802 & 6.918 \\
\hline $\operatorname{Lr} 28, \operatorname{Lr} 29, \operatorname{Lr} 35$ & 11870 & 9.83 \\
\hline $\operatorname{Lr} 28, \operatorname{Lr} 35, \operatorname{Lr} 39$ & 11871 & 7.35 \\
\hline 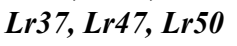 & 10879 & 11.25 \\
\hline $\operatorname{Lr} 37, \operatorname{Lr} 46, \operatorname{Lr} 51$ & 10814 & 9.24 \\
\hline $\operatorname{Lr} 25, \operatorname{Lr} 27, \operatorname{Lr} 46$ & Pak-81 & 9.81 \\
\hline $\operatorname{Lr} 27, \operatorname{Lr} 50, \operatorname{Lr} 51$ & Atta Habib & 11.98 \\
\hline $\operatorname{Lr} 27, \operatorname{Lr} 37, \operatorname{Lr} 47$ & Kaghan93 & 11.53 \\
\hline $\operatorname{Lr} 47, \operatorname{Lr} 50, \operatorname{Lr} 51$ & Faisalabad08 & 10.09 \\
\hline $\operatorname{Lr} 20, \operatorname{Lr} 27$ & 10748 & 6.457 \\
\hline Lr24, Lr27 & 10798 & 8.86 \\
\hline Lr25, Lr27 & $10805,10758,10742,10807$ & $13.54,15.65,14.02,12.81$ \\
\hline $\operatorname{Lr} 28, \operatorname{Lr} 35$ & $\mathbf{1 0 7 7 4}, 10753,10736, \mathbf{1 0 8 1 2}, \mathbf{1 0 7 3 1}, \mathbf{1 0 7 1 6}, \mathbf{1 0 7 5 4}, \mathbf{1 0 7 2 0}$ & $\begin{array}{l}\text { 11.66, } 8.49,9.71,10.29,20.62,10.22 \\
18.84,13.06\end{array}$ \\
\hline $\operatorname{Lr} 29, \operatorname{Lr} 35$ & 10744 & 12.14 \\
\hline Lr37, Lr51 & $10821,10759,10725$ & $4.63,16.36,11.24$ \\
\hline Lr37, $\operatorname{Lr} 47$ & 10755, Gomal & $8.04,7.04$ \\
\hline $\operatorname{Lr} 28, \operatorname{Lr} 29$ & 10767 & 16.63 \\
\hline Lr37, Lr46 & 10819 & 6.01 \\
\hline $\operatorname{Lr} 37, \operatorname{Lr} 50$ & 10743 & 9.75 \\
\hline Lr46, $\operatorname{Lr} 50$ & 10730 & 6.83 \\
\hline Lr46, $\operatorname{Lr} 51$ & 10875,10732 & $9.30,10.32$ \\
\hline $\operatorname{Lr} 47, \operatorname{Lr} 51$ & 11882 & 7.08 \\
\hline $\operatorname{Lr} 47, \operatorname{Lr} 50$ & 10771 & 6.74 \\
\hline $\operatorname{Lr} 50, \operatorname{Lr} 51$ & 10877 & 9.57 \\
\hline $\operatorname{Lr} 25, \operatorname{Lr} 47$ & Suliman96 & 12.75 \\
\hline Lr27, $\operatorname{Lr} 47$ & KT-2000 & 7.37 \\
\hline $\operatorname{Lr} 28, \operatorname{Lr} 29$ & Zam & 9.77 \\
\hline $\operatorname{Lr} 9, \operatorname{Lr} 10$ & $\begin{array}{l}\text { Punjab96, Mumal2002, Zamindar80, Iqbal2000, SH2003, Anmol94, } \\
\text { LU26, Chenab96, Faisalabad83, Zarghoon79, C228, Shahkar95, } \\
\text { Nuri70, Punjab81, Sutlaj86, Blue Silver, RWP94, Pirsabak85 }\end{array}$ & $\begin{array}{l}4.83,5.03,4.78,5.36,6.66,5.43,7.26 \\
5.63,6.83,6.26,5.13,6.46,6.16,5.40 \\
4.83,9.16,5.93,6.36\end{array}$ \\
\hline $\operatorname{Lr} 25$ & $\mathbf{1 0 8 0 0}, \mathbf{1 0 7 7 6}, 10769,10765$ & $\mathbf{1 2 . 1 2}, \mathbf{1 0 . 7 1}, 8.15,8.85$ \\
\hline Lr27 & 10799, 10786, 10785 & $11.57, \mathbf{1 2 . 2 5}, 8.56$ \\
\hline Lr28 & $\begin{array}{l}10750, \mathbf{1 0 7 7 7}, 10770,10757,10739, \\
10749 \mathbf{1 1 8 6 9} \mathbf{1 0 7 5 6} 10787 \text { PS05 }\end{array}$ & 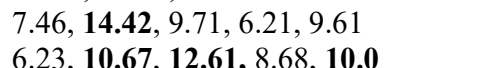 \\
\hline
\end{tabular}




\begin{tabular}{|c|c|c|}
\hline $\operatorname{Lr29}$ & 10741, 10728, Saleem-2000 & $9.20, \mathbf{1 2 . 6}, 9.6$ \\
\hline $\operatorname{Lr} 35$ & $\begin{array}{l}\text { 10781, 10752, } 11872,10773,10745, \\
\mathbf{1 0 8 0 6}, \mathbf{1 0 7 2 1}\end{array}$ & $\begin{array}{l}9.77, \mathbf{1 2 . 5 0}, 8.50,5.78,4.66 \\
\mathbf{1 0 . 7 2}, \mathbf{1 6 . 7 6}\end{array}$ \\
\hline $\operatorname{Lr} 37$ & 10818, 11876, 10780, 10740, Lasani08 & $7.50, \mathbf{1 0 . 0}, 4.90,6.22,6.30$ \\
\hline $\operatorname{Lr} 46$ & $10816,10718, \mathbf{U q a b 2 0 0 0}$ & $4.74,7.92, \mathbf{1 1 . 9 0}$ \\
\hline $\operatorname{Lr} 50$ & 10878,10815 & $10.15,13.15$ \\
\hline $\operatorname{Lr} 51$ & $10813,10803,10772, \mathbf{1 0 8 0 9}, \mathbf{1 0 7 1 7}, 10810$ & $5.51,7.26,6.54,8.81, \mathbf{1 0 . 7 0}, \mathbf{1 1 . 5 2}$ \\
\hline $\operatorname{Lr} 58$ & $10874,10827,10820$ & $11.90,15.48,11.28$ \\
\hline $\operatorname{Lr61}$ & $\begin{array}{l}11868,10854, \mathbf{1 1 8 6 0}, 11809, \mathbf{1 0 8 2 9}, \mathbf{0 8 5 2} \\
\mathbf{1 0 8 3 4}, 10831, \mathbf{1 1 8 6 5}, \mathbf{1 0 8 2 2}, \mathbf{1 1 8 8 1}, \mathbf{1 1 8 7 4}\end{array}$ & $\begin{array}{l}7.35,9.32, \mathbf{1 1 . 2 2}, 7.81, \mathbf{1 0 . 1}, \mathbf{1 3 . 1 2} \\
\mathbf{1 2 . 7 2}, 9.40, \mathbf{1 1 . 6 4}, \mathbf{1 9 . 5 3}, \mathbf{1 6 . 1 4}, \mathbf{1 1 . 9 0}\end{array}$ \\
\hline $\operatorname{Lr} 9$ & $\begin{array}{l}\text { Anza+2NS, AUP5000, WL711, SA75, SA42, } \\
\text { Marvat01, Dirk, Lasani08, Sandal, Kiran }\end{array}$ & $\begin{array}{l}4.6,5.23,5.33,6.26,5.63 \\
5.40,8.33,6.30,4.83,4.66\end{array}$ \\
\hline $\operatorname{Lr} 10$ & $\begin{array}{l}\text { C-228, C-591, C-250, Sariab92, Barani-83, } \\
\text { Kohinoor83, Potohar70, C-273 }\end{array}$ & $\begin{array}{l}5.13,6.10,6.6,6.76,3.73 \\
5.06,5.2,6.63\end{array}$ \\
\hline
\end{tabular}

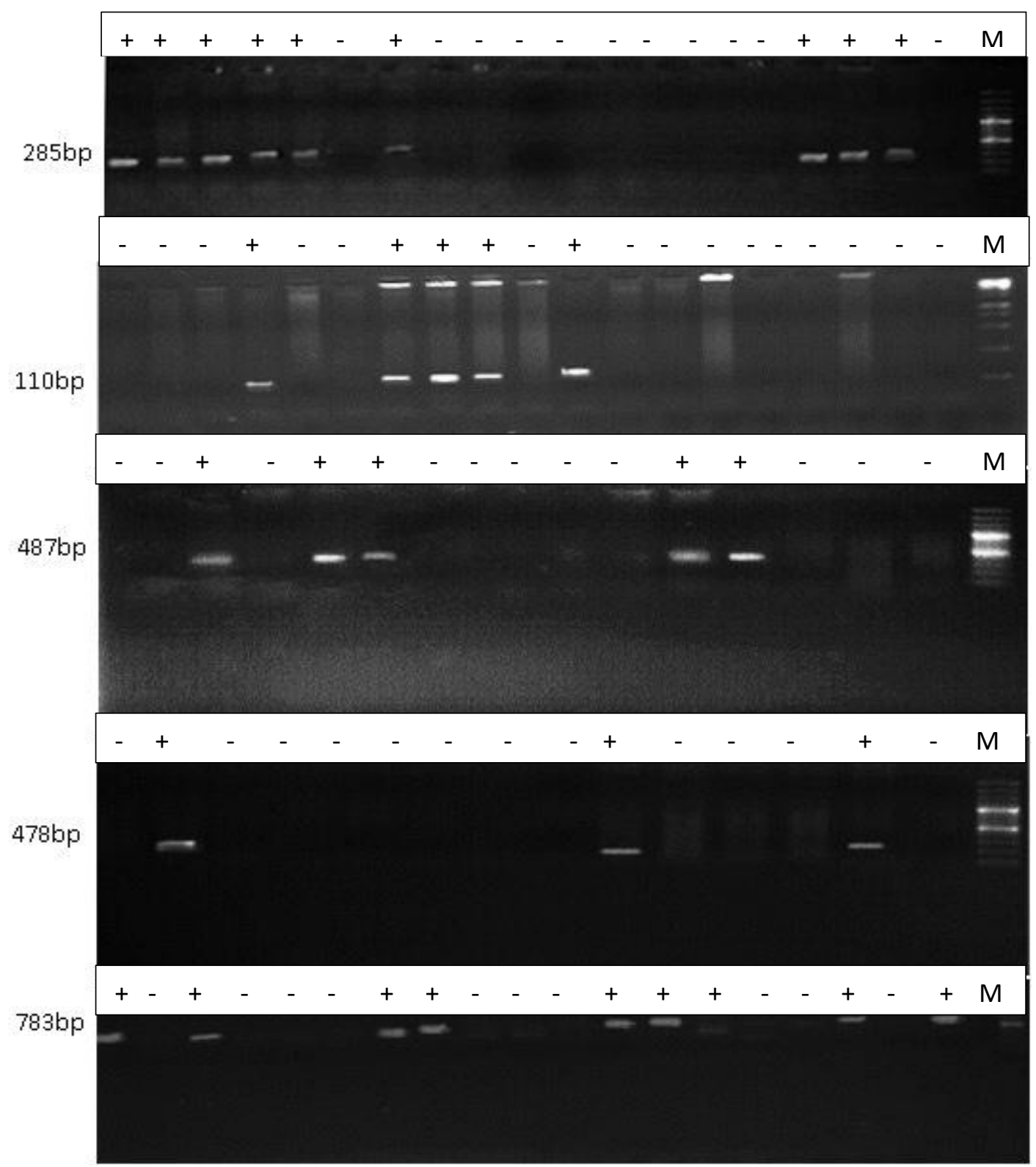

Fig. 1. Selected gel picture of some genes studied $M=100 \mathrm{bp}$ marker (A) Amplification profile of Lr37. (B) Amplification profile of Lr46 (C) Amplification profile of Lr 47. (D) Amplification profile of Lr 50 (E) Amplification profile of Lr 51. 


\section{DISCUSSION}

To survive and sustain, pathogens respond positively to the selection pressure of the host and environment with fast genetic changes. This results into the emergence of new races of pathogens. In context of this ever-evolving nature of the pathogens, a single genederived resistance is neither broad nor durable, and thus, any time soon, can be defeated by the emergence of the new virulent races of the pathogen. In USA, for example, $\operatorname{Lr} 9$ gene conferred resistance to soft red winter wheat in the 1970s against leaf rust only for few years. In another example, the races of leaf rust which could defeat $L r 41$ and $L r 50$ genes were identified in USA even before the cultivars harboring these genes could be released (Kolmer et al., 2007a). Similarly, races having virulence to $L r 19, L r 26, L r 41$ and $L r 51$ have been identified in Argentina in cultivars that originally were resistant to leaf rust (Vanzetti et al., 2011). Therefore, pyramiding more than one effective resistance genes in a single background can enhance the spectrum and durability of the rust resistance. Hard red spring wheat cultivars having Lr16 and $L r 24$ were highly resistant to leaf rust (Oelke and Kolmer 2004). The development of wheat germplasm with high level of resistance will, therefore, depend on the ability to select genotypes that have combinations of effective resistance genes such as $L r 16, L r 23$ and $L r 34$ genes as suggested by Kolmer et al., (2007a). In Argentina, however, resistant local cultivars were detected for the presence of $\operatorname{Lr} 16$ gene but not $L r 34$ and $L r 23$ genes. The results propose the possibility that $\operatorname{Lr} 16$, in combination with some unknown $L r$ gene(s) other than $L r 23$ and $L r 34$, gives a high level of resistance relative to different geo-ecological environments (Vanzetti et al., 2011).

Gene pyramiding of $L r$ genes is, therefore, an effective strategy to develop broad and durable resistance in wheat cultivars against leaf rust. MAS has been well understood and applied to follow the genes of interest in germplasm and varieties. It is an effective way for identification and pyramiding of disease resistance genes into a single variety. In breeding for leaf rust resistance in wheat, PCR-based markers are already available for around 30 resistance genes and alleles (Samsampour et al. 2010). Some of the markers appropriate for seedling resistance include $\operatorname{Lr} 9$ (Schachermayr et al. 1994; Gupta et al. 2005), Lr16 (McCartney et al. 2005), Lr19 (Prins et al. 2001; Gupta et al. 2006), Lr41 (Sun et al. 2009), Lr51 (Helguera et al. 2005), Lr Lr53 (Dadkhodaie et al. 2010), Lr56 (Marais et al. 2010a), Lr57 (Kuraparthy et al. 2009), Lr59 (Marais et al. 2008), Lr62 (Marais et al. 2009), Lr63 (Kolmer et al. 2010), and Lr66 (Marais et al. 2010b). The markers associated with adult plant resistance genes are Lr12 (Singh and Bowden, 2010), Lr22a (Hiebert et al. 2007), SV2 (Ingala et al. 2007), Lr46 (Mateos-Hernandez et al. 2006), Lr48 (Singh et al.
2011) and Lr67 (Herrera-Foessel et al, 2011) are available along with ones used in the current study.

Substantial efforts have been made and are being put together to develop genomic resources for different plant species of economic importance, wheat being one of them (Schreiber et al. 2012). Innovations in mapping and sequencing tools have increased the number of effective $L r$ genes showing partial resistance (slow rusting) at seedling or adult plant stages. This has broadened the pool of available $L r$ genes and provided a flexibility to deploy a combination of $L r$ genes for broad and durable resistance against the rapidly evolving strains of rust pathogens. Multiple minor or major, adult or seedling plants-resistance genes need to be combined for the optimal level of durable and broad-spectrum resistance. Through this strategy, the resistance response of the plants to rust can be exploited in two ways i.e basal resistance mediated by minor genes and race-specific resistance mediated by major genes. A rigorous assessment of host fitness of the combined genes deployment in terms of agronomic characteristics including phenotype and yield will be needed to either acquire or discard this new modulated strategy. The presence of $L r$ genes, as triplet, doublet or singlet, in different number of varieties/germplasms in the current study showed the dynamic nature of the immunity of these varieties/germplasms. Based on MAS, the genotypes positive for $L r$ genes in the present study can be valuable resources for future breeding for rust resistance and high grain yield programs.

\section{Compliance with Ethical Standards}

Disclosure of potential conflicts of interest: None to declare.

\section{Research involving Human Participants and/or Animals: None to declare.}

Informed consent: None to declare.

Conclusions: In the present study, 254 Pakistani wheat germplasm were screened for the presence/absence of 17 leaf rust resistance $(L r)$ genes. Triple and double $L r$ genes pyramids were detected in 9 and 50 varieties/germplasm, respectively, while single $L r$ genes were detected in 29 varieties/germplasm. Germplasm 10731, having the $L r 28 / L r 35$ combination, was the leading germplasm with highest grain yield of $20.62 \mathrm{~g} / \mathrm{plant}$. Other leading germplasm included 10754, 10767 and 10758, having combinations of $L r 28 / L r 35, L r 28 / L r 29$ and $L r 25 / L r 27$, and grain yield of $18.84,16.63$ and 15.65 , respectively.

\section{REFERENCES}

Afzal, M.I. and M. A. Iqbal (2015). Plant nutrients supplementation with foliar application of allelopathic water extracts improves wheat 
(Triticum aestivum L.) yield. Advance in Agriculture and Biology, 4(2): 64-70.

Brown-Guedira, G.L., S. Singh, A.K. Fritz, (2003). Performance and mapping of leaf rust resistance transferred to wheat from Triticum timopheevii subsp. armeniacum. Phytopathology. 93:784789.

Brunel, D., 1992. An alternative, rapid method of plant DNA extraction for PCR analyses. Nucleic Acids Research, 20(17): 4676.

Dadkhodaie, N.A., H. Karaoglou, C.R. Wellings, and R.F. Park, (2010). Mapping genes Lr53 and Yr35 on the short arm of chromosome 6B of common wheat with microsatellite markers and studies of their association with Lr36. Theoretical and Applied Genetics. 122(3): 479487.

Dangl, J.L., and J.D.G. Jones (2001). Plant pathogens and integrated defense responses to infection. Nature 411: 826-833.

Gold, J., D. Harder, F. Townley-Smith, T. Aung and J. Procunier, (1999). Development of a molecular marker for rust resistance genes $\mathrm{Sr} 39$ and $\operatorname{Lr} 35$ in wheat breeding lines. Electronic J. Biotechnology. 2: 1.

Gupta, S.K., A. Charpe, S. Koul, K.V. Prabhu, and Q.M.R. Haq, (2005). Development and validation of molecular markers linked to an Aegilops umbellulata-derived leaf rustresistance gene, $L r 9$, for marker-assisted selection in bread wheat. Genome. 48(5): 823830.

Gupta, S.K., A. Charpe, K.V. Prabhu, and Q.M.R. Haque, (2006). Identification and validation of molecular markers linked to the leaf rust resistance gene $L r 19$ in wheat. Theoretical and Applied Genetics. 113(6): 1027-1036.

Helguera, M., I.A. Khan, J. Dubcovsky, (2000). Development of PCR markers for the wheat leaf rust resistance gene $L r 47$. Theor. Appl. Genet.100: 1137-1143.

Helguera, M.L., S.M. Vanzetti, I.A. Khan, J. Kolmer, J.D. Dubcovsky, (2005. Markers for triticum speltoides leaf rust resistance gene Lr51 and their use to develop nearisogenic lines. Crop Sci. 45: 728-734.

Helguera, M., I.A. Khan, J. Kolmer, D. Lijavetzki, L. Zhong-Qi, and J. Dubcovsky, (2003). PCR assays for the Lr37-Yr17-Sr38 cluster of rust resistance genes and their use to develop isogenic hard red spring wheat lines. Crop Science. 43(5): 1839-1847

Herrera-Foessel, S.A., R.P. Singh, J. Huerta-Espino, J. Yuen, and A. Djurle, (2005). New genes for leaf rust resistance in CIMMYT durum wheat. Plant Dis. 89:809-814.
Herrera-Foessel, S.A., E.S. Lagudah, J. Huerta-Espino, M.J. Hayden, H.S. Bariana, D. Singh, and R.P. Singh, (2011). New slow-rusting leaf rust and stripe rust resistance genes $\operatorname{Lr67}$ and Yr46 in wheat are pleiotropic or closely linked. Theoretical and Applied Genetics. 122(1): 239249.

Hiebert, C.W., J.B. Thomas, D.J. Somers, B.D. Mccallum, and S.L. Fox, (2007). Microsatellite mapping of adult-plant leaf rust resistance gene Lr22a in wheat. Theoretical and Applied Genetics. 115(6):877-884

Inamullah., A. Habib, F. Muhammad, S. Din, G. Hassan, R. Gul, (2006). Diallel analysis of the inheritance pattern of agronomic traits of bread wheat. Pakistan J.Bot. 38(4):1169-1175.

Ingala, L., H. Saione, M. Helguera, M. Nisi, and F. Sacco, (2007). Inheritance of adult plant resistance genes and associated markers from a durable resistant cultivar to leaf rust. In: BUCK, H.T.; NISI, J.E. and SALOMÓN, N. eds. Wheat Production in Stressed Environments. Dordrecht, Springer, 12: 59-63.

Jin, Y., and R.P. Singh, (2006). Resistance in U.S. wheat to recent Eastern African isolates of Puccinia graminis $\mathrm{f}$. sp. tritici with virulence to resistance gene Sr31. Plant Disease. 90:476-480.

Kolmer, J.A., J.A. Anderson, and J.M. Flor, (2010). Chromosome location, linkage with simple sequence repeat markers, and leaf rust resistance conditioned by gene Lr63 in wheat. Crop Science. 50(6): 2392-2395.

Kolmer, J.A., Y. Jin and D.L. Long, (2007a). Wheat leaf and stem rust in the United States. Australian J. Agricultural Research. 58(6): 631-638.

Kuraparthy, V., S. Sood, P. Chhuneja, H.S. Dhaliwal, S. Kaur, R.L. Bowden, and B.S. Gill, (2007). A cryptic wheat-Aegilops triuncialis translocation with leaf rust resistance gene $L r 58$. Crop Sci. 47:1995-2003.

Kuraparthy, V., S. Sood, D.R. See, and B.S. Gill, (2009). Development of a PCR assay and markerassisted transfer of leaf rust and stripe rust resistance genes Lr57 and Yr40 into hard red winter wheat. Crop Science. 49(1): 120-126.

Lagudah, E.S., H. Mcfadden, R.P. Singh, J. HuertaEspino, H.S. Bariana and W. Spielmeyer, (2006). Molecular genetic characterisation of the Lr34/Yr18 slow rusting resistance gene region in wheat. TAG Theoretical and Applied Genetics. 114(1): 21-30.

Mago, R., L. Tabe, R. A. McIntosh, Z. Pretorius, R. Kota, E. Paux, T. Wicker, J. Breen, E.S. Lagudah, J.G. Ellis, W. Spielmeyer. (2011). A multiple resistance locus on chromosome arm 3BS in wheat confers resistance to stem rust 
(Sr2), leaf rust (Lr27) and powdery mildew. Theor Appl Genet. 123:615-623.

Marais, F., A. Marais, B. Mccallum, and Z. Pretorius, (2009). Transfer of leaf rust and stripe rust resistance genes Lr62 and Yr42 from Aegilops neglecta Req. ex Bertol. to common wheat. Crop Science. 49(3): 871-879

Marais, G.F., P.E. Badenhorst, A. Eksteen, and Z.A. Pretorius, (2010a). Reduction of Aegilops sharonensis chromatin associated with resistance genes Lr56 and Yr38 in wheat. Euphytica. 171(1): 15-22

Marais, G.F., T.A. Bekker, A. Eksteen, B. Mccallum, T. Fetch, and A.S. Marais, (2010b). Attempts to remove gametocidal genes co-transferred to common wheat with rust resistance from Aegilops speltoides. Euphytica. 171(1): 71-85.

Marais, G.F., B. Mccallum, and A.S. Marais, (2008). Wheat leaf rust resistance gene Lr59 derived from Aegilops peregrina. Plant Breeding. 127(4): 340-345.

Marasas, C., M. Smale, and R.P. Singh, (2004). The economic impact in developing countries of leaf rust resistance breeding in CIMMYT related spring bread wheat. Economics program paper. 04-01. Mexico: CIMMYT.

Mateos-Hernandez, M., R.P. Singh, S.H. Hulbert, R.L. Bowden, J. Huerta-Espino, B.S. Gill, and G. Brown-Guedira, (2006). Targeted mapping of ESTs linked to the adult plant resistance gene Lr46 in wheat using synteny with rice. Functional \& Integrative Genomics. 6(2): 122131.

Mccartney, C.A., D.J. Somers, B.D. Mccallum, J. Thomas, D.G. Humphreys, J.G. Menzies, and P.D. Brown, (2005). Microsatellite tagging of the leaf rust resistance gene $\operatorname{Lr} 16$ on wheat chromosome 2BSc. Molecular Breeding. 15(4): 329-337.

Mebrate, S.A., E.C. Oerke, H.W. Dehne, and K. Pillen, (2008). Mapping of the leaf rust resistance gene Lr38 on wheat chromosome arm 6DL using SSR markers. Euphytica. 162(3): 457-466.

Messmer, M.M., R. Seyfarth, M. Keller, G. Schachermayr, M. Winzeler, S. Zanetti, C. Feuillet, and B. Keller, (2000). Genetic analysis of durable leaf rust resistance in winter wheat. TAG Theoretical and Applied Genetics. 100(3): 419-431.

Naik, S., K.S. Prakasa, V.S. Rao, V.S. Gupta, S.A. Tamhankar, S. Pujar, B.S. Gill and P.K. Ranjekar, (1998). Identification of a STS marker linked to the Aegilops speltoides -derived leaf rust resistance gene $L r 28$ in wheat. Theor Appl Genet. 97: 535-540
Narang, D., S. Kaur, B. Steuernagel, S. Ghosh, R. Dhillon, M. Bansal, C. Uauy, B. B. Wulff and P. Chhuneja, (2019). Fine mapping of Aegilops peregrina co-segregating leaf and stripe rust resistance genes to distal-most end of 5DS. Theoretical and Applied Genetics 132(5): 1473 1485.

Neu, C., N., and B. Keller, (2002). Genetic Mapping of the Lr20-Pm1 Resistance Locus Reveals Suppressed Recombination on Chromosome Arm 7AL in Hexaploid Wheat, Genome. 45: 737-744.

Oelke, L.M, and J.A. Kolmer, (2004). Characterization of leaf rust resistance in hard red spring wheat cultivars. Plant Disease. 88(10): 1127-1133.

Paux, E., P.Sourdille, J. Salse, C.Saintenac, F. Choulet, P. Leroy, and E. Lagudah, (2008). A physical map of the 1-gigabase bread wheat chromosome 3B. Science. 322(5898): 101-104.

Prins, R., J.Z. Groenewald, G.F. Marais, J.W. Snape, and R.M.D. Koebner, (2001). AFLP and STS tagging of $L r 19$, a gene conferring resistance to leaf rust in wheat. Theoretical and Applied Genetics. 103(4): 618-624.

Procunier, J.D., T.F. Townley-Smith, S. Fox, S. Prashar, M. Gray, W.K. Kim, E. Czarnecki, and P.L. Dyck, (1995). PCR-based RAPD/DGGE markers linked to leaf rust resistance genes $L r 29$ and $L r 25$ in wheat (Triticum aestivum L.). J. Genetics and Breeding. 49: 87-92.

Raupp, W.J., S. Sukhwinder, G.L. Brown-Guedira, and B.S. Gill, (2001). Cytogenetic and molecular mapping of the leaf rust resistance gene $L r 39$ in wheat. Theor. Appl. Genet. 102:347-352.

Rosewarne, G.M., R.P. Singh, J. Huerta-Espino, H.M. William, S. Bouchet, S. Cloutier, H. McFadden, and E.S. Lagudah, (2006). Leaf tip necrosis, molecular markers and b1-proteasome subunits associated with the slow rusting resistance genes Lr46/Yr29. Theor. Appl. Genet. 112: 500-508.

Samsampour, D., B. Maleki Zanjani, J.K. Pallavi, A. Singh, A. Charpe, S.K. Gupta, and K.V. Prabhu, (2010). Identification of molecular markers linked to adult plant leaf rust resistance gene Lr48 in wheat and detection of $L r 48$ in the Thatcher near-isogenic line with gene Lr25. Euphytica. 174(3): 337-342.

Schachermayr, G., M. Messemer, and C. Feuillet, (1995). Identification of Molecular Markers Linked to the Agropyron elongatum-Derived Leaf Rust Resistance Gene Lr24 in Wheat, Theor. Appl. Genet. 90: 982-990.

Schachermayr, G., C. Feuillet, and B. Keller, (1997). Molecular markers for the detection of the wheat leaf rust resistance gene $L r 10$ in diverse genetic backgrounds. Molecular Breeding. 3(1): 65-74. 
Schachermayr, G., Siedler, M.D. Gale, H. Winzeler, M. Winzeler, and B. Keller, (1994). Identification and localization of molecular markers linked to the $\operatorname{Lr} 9$ leaf rust resistance gene of wheat. Theoretical and Applied Genetics. 88(1): 110115.

Schreiber, A.W., M.J. Hayden., K.L. Forrest, S.L. Kong, P. Langridge, and U. Baumann, (2012). Transcriptome-scale homoeolog-specific transcript assemblies of bread wheat. BMC genomics. 13(1): 492.

Schulze-Lefert, P., and S. Bieri, (2005). Recognition at a distance. Science. 308: 506-508.

Shiferaw, B., M. Smale, H.J. Braun, E. Duveiller, M. Reynolds, G. Muricho, (2013). Crops that feed the world. Past successes and future challenges to the role played by wheat in global food security. Food Sec. 5: 291-317.

Singh, P.K., and G.R. Hughes, (2006). Genetic similarity among isolates of Pyrenophoratriticirepentis, causal agent of tan spot of wheat. J. Phytopathology. 154:178-184.

Singh, A., J.K. Pallavi, P. Gupta, and K.V. Prabhu, (2011). Identification of microsatellite markers linked to leaf rust adult plant resistance (APR) gene Lr48 in wheat. Plant Breeding. 130(1): 3134.
Singh, R.P., D.P. Hodson, J. Huerta-Espino, Y. Jin, S. Bhavani, P. Njau, et al., (2011). The emergence of $\mathrm{Ug} 99$ races of the stem rust fungus is a threat to world wheat production. Annual Review of Phytopathology 49: 465-481.

Singh, S., and R.L. Bowden, (2010). Molecular mapping of adult-plant race-specific leaf rust resistance gene $\operatorname{Lr} 12$ in bread wheat. Molecular Breeding. on line first

Sun, X., G. Bai, and B.F. Carver, (2009). Molecular markers for wheat leaf rust resistance gene $L r 41$. Molecular Breeding. 23(2): 311-321.

Vanzetti, L.S., P. Campos, M. Demichelis, L.A. Lombardo, P.R. Aurelia, L.M. Vaschetto, C.T. Bainotti, and M. Helguera, (2011). Identification of leaf rust resistance genes in selected Argentinean bread wheat cultivars by gene postulation and molecular markers. Electronic J. Biotechnology. 14(3) http://dx.doi.org/ 10.2225 /vol14-issue3-fulltext-14

Zeng, Q., J. Wu, S. Liu, S. Huang, Q. Wang, J. Mu, S. $\mathrm{Yu}, \mathrm{D}$. Han, and Z. Kang, (2019). A major QTL co-localized on chromosome 6BL and its epistatic interaction for enhanced wheat stripe rust resistance. Theoretical and Applied Genetics, 132(5): 1409-1424. 